\title{
The discourse of dependency and the agrarian roots of welfare doctrines in Africa: The case of Botswana'
}

\author{
Jeremy SEEKINGS
}

University of Cape Town

\begin{abstract}
Political elites across much of Africa have criticized welfare programmes and the idea of a welfare state for fostering dependency. Anxiety over dependency is not unique to East or Southern Africa, but the discourse of dependency in countries such as Botswana differs in important respects to the discourses of dependency articulated in some industrialised societies (notably the USA). This paper examines African discourses of dependency through a case-study of Botswana. The paper traces the genealogy of dependency through programmatic responses to drought between the 1960s and 1990s, and a reaction in the 2000s. The growth of a discourse of dependency reflected both social and economic concerns: Socially, it was rooted in pre-existing understandings of the reciprocal responsibilities associated with kinship and community; economically, the emergence of a discourse of dependency reflected the rise of an approach to development rooted in nostalgic conceptions of hard-working small farmers. The discourse of dependency appealed to both conservatives (offended by anti-social individualism) and economic modernisers (eager for an explanation for the failures of the developmental project to eliminate poverty).
\end{abstract}

Keywords: Botswana, dependency, social assistance, welfare, discourse

\section{Introduction}

Welfare states in Africa are distinguished by their design as well as their apparently low overall level of expenditure. Most Anglophone countries in Africa emphasise forms of social assistance - with benefits in cash or kind, including in response to drought - rather than social insurance. Social assistance programmes, mostly aimed at the permanently or temporarily poor, are large relative to social insurance programmes aimed at the minority of workers in

\footnotetext{
${ }^{1}$ This paper builds on research funded by an award from the UK Department for International Development through the UK Economic and Social Research Council for a project on Legislating and Implementing Welfare Policy Reforms. Some of the arguments were rehearsed in a previous paper (Seekings 2016c).

${ }^{2}$ Jeremy Seekings is Professor of Political Studies and Sociology at the University of Cape Town and Visiting Professor of Political Science at the Macmillan Centre for International and Area Studies, Yale. Furthermore, he is Director of the Centre for Social Science Research and Interim Director of the Institute for Democracy, Citizenship and Public Policy in Africa. Jeremy.Seekings@uct.ac.za.
} 
formal employment. Low levels of total expenditure are explained primarily by the absence of social insurance programmes, which in turn is due primarily to the level and character of economic development, with limited industrialization or other formal employment. Social assistance programmes, on the other hand, have become widespread, having often grown out of drought relief and recovery programmes. There is no relationship between the level of economic development and expenditure (in relation to GDP) on social assistance programmes. This pattern reflects the fact that African welfare states have developed with the primary objective of protecting their citizens against the risks inherent in agrarian economies, whereas the welfare states of most of Europe, North America and even Latin America tend to protect their citizens against the risks associated with industrialization (Seekings 2016d, 2018).

Social assistance programmes may be relatively extensive across much of East and Southern Africa, and are becoming more widespread (Garcia/Moore 2012). This does not mean that they are uncontroversial. On the contrary, social assistance programmes have attracted widespread criticism for fostering dependency on the state, rewarding sloth, and undermining both economic production and social responsibility. Political elites across much of Africa favour the imposition of conditionalities to reduce the likelihood of dependency. Most social assistance programmes in Africa are targeted on the poor through means-tests. Many entail workfare, with benefits tied to participation in public employment programmes. Benefits (and wages for workfare) are often kept low in part to discourage non-poor applicants. Some national policy-makers have even argued for the imposition of the kinds of behavioural conditions that characterize (at least notionally) many conditional cash transfer programmes in Latin America - even when the World Bank and other champions of conditional cash transfers point out that these conditions make little or no sense in African conditions. These conditions seem to have been insufficient to prevent the perception that dependency is widespread.

The spectre of dependency has been powerfully invoked by a former minister in Botswana, David Magang. Magang's ministerial positions included spells as Deputy-Minister of Finance and Development Planning in 1984-85 and 1992-94. In his memoirs, Magang argued that:

"In today's Botswana, the culture of dependence, as opposed to one of selfresourcefulness, is omnipresent and the blame lies squarely with government. Instead of encouraging its citizens to stand on their own two feet, government has tended to spoon-feed and at times force-feed them. It has created a haven of handouts from which it is well-nigh impossible to wean them. [...] There are just too many free or easy-to-acquire things in Botswana and, for a country that is of limited endowment, this amounts to profligacy. Batswana ${ }^{3}$ are so used to give-aways that they cannot nurture a sustained entrepreneurial spirit; whatever business undertaking they indulge in has to be underwritten, directly or indirectly, by government." (Magang 2008: 402, 509).

Magang wrote this prior to the massive expansion of workfare in Botswana under President Ian Khama. In Botswana today, almost ten years later, almost all middle class Batswana express anxiety about dependency on government handouts. In Magang's opinion, which is

${ }^{3}$ The word Batswana refers to the Tswana people. 
shared by government ministers and officials across much of East and Southern Africa, what is needed is education and training, or empowerment, not handouts.

In this paper I argue that the coincidence of relatively important social assistance programmes with a strong ideological criticism is not as paradoxical as it might seem. The discourse of dependency in East and Southern Africa reflects the same agrarian roots as the design of the welfare state across most of the region. In countries like Botswana, the welfare state developed to address the risks faced by peasants (or former peasants) as a result of drought and, especially in the 1990s and 2000s, social and economic change. The discourse of dependency emerged as an ideological expression of concern over the decline, in both social and economic terms, of agrarian society. The discourse of dependency thus constitutes a distinctively agrarian doctrine of welfare. In this it differs from the discourse of dependency in the USA, for example, as we shall see further below.

This paper focuses on the case-study of Botswana. I cannot demonstrate but think that it is likely that this discourse of dependency is unusually prevalent in Botswana, fueled by both an unusually extensive (but not generous) welfare state, rapid economic growth and the social change associated with deagrarianisation. The discourse of dependency is widespread across East and Southern Africa, however, and I think that it is likely that the key features of the discourse in Botswana are typical of the region as a whole, even if they are more pronounced than in some other countries. Moreover, in Botswana more than elsewhere in the region, the discourse of dependency was offset - at least until the late 1990s - by a counter-veiling discourse of responsibility, which was probably stronger in Botswana than elsewhere. The final section of this paper will return to this question of the extent to which Botswana has been typical or exceptional.

The first part of this paper traces the genealogy of a discourse of dependency between the 1960s and 1990s. I show that the discourse was largely absent during the 1960s and 1970s, despite the rapid expansion of public provision through drought relief and recovery programmes. Successive Botswana Democratic Party (BDP) governments began to build a welfare state that was extensive in terms of coverage but was conservative in several respects: Most benefits were modest and paid in kind rather than cash, in part through workfare, with the explicit goal of protecting both family and community. The president and vice-president, Seretse Khama and Quett Masire, developed a conservative welfare doctrine that emphasized a balance between self-reliance and shared responsibilities. Further droughts between the late 1970s and late 1980s prompted explicit concern with dependency, first among development experts and the personnel of the primary international drought relief agency, the World Food Programme (WFP), and later (in the 1990s) among government officials and ministers.

Despite these growing misgivings, the welfare state continued to expand in the 1990s, with the introduction of new programmes that persisted through non-drought years also. The second part of this paper examines the reaction to this in the 2000s, when criticisms of dependency became hegemonic in Botswana. This informed a further shift towards workfare as well as the rejection of several proposals for the expansion of cash transfer programmes.

The final section of the paper draws out the key themes in the discourse of dependency in Botswana. Not only did the doctrine emerge around government programmes to address drought and poverty in rural areas, but it also drew on an ideology of responsibility that was 
firmly rooted in agrarian social relations. These agrarian dimensions distinguish the discourse of dependency in Botswana from the discourse that developed in industrializing societies such as the USA. This is not to say that the agrarian society imagined by conservative elites in Botswana could be realized. As Ferguson (2015) emphasises, the absence of economic opportunities for the poor - whether in rural or urban areas - leaves many poor people across Southern Africa with no choice but to be dependent on either kin or the state. Dependency is a necessity for survival, not a choice.

This paper is not concerned with the reality of livelihoods as much as the discourses used by elites to frame and legitimate their policy choices. I build on Ferguson's work through a careful periodization and close analysis of the evolution of the public discourse of dependency in one country. Changes in the discourse over time enable us to identify the roles played by indigenous norms about reciprocity in social relations and the norms of development that were articulated most strongly by external agencies and experts. This paper draws primarily on the fragmentary sources available through documents in archives and elsewhere, and this necessarily generates an incomplete picture. The eminent anthropologist of Botswana, Ørnulf Gulbrandsen, conducted sustained ethnographic research between the 1970s and 1990s. He found that „in private conversations politicians and bureaucrats consistently emphasized the danger of providing too many direct subsidies for the poor people, these being, in their view, likely to encourage laziness“. But such views „never surface in public where it is constantly argued that the interests of rich and poor are not competing" (1996: 367, fn 2). It is possible, or even likely, that the private discourses of elites changed more rapidly than the public discourse, but this cannot easily be demonstrated.

\section{Drought, self-help and dependency between the 1960 s and 1990s}

Through the twentieth century, drought was the most important risk pushing people into destitution and even starvation across much of Africa. Botswana was especially vulnerable, not only because it was one of the poorest countries in the world at the time of Independence, but rainfall was low even in good years and drought often affected the entire country rather than specific areas within it. Independence (in 1966) coincided with the worst drought in living memory, and very severe drought recurred repeatedly over the following decades, especially in 1978/79, 1981-87 and 1992/93. The implementation of drought relief and recovery programmes preoccupied successive Botswana Democratic Party (BDP) governments, and redefined the relationship between the new state and its citizens. Under presidents Seretse Khama (1966-80), Quett Masire (1980-98) and Festus Mogae (1998-2008), the BDP and government developed and revised an ideology of governance that entailed a strong emphasis on the responsibility of the state for the poor. Anxiety over dependency entered into public expressions of this ideology slowly, as temporary drought relief gave way to permanent programmes.

Faced with drought in 1965-66 and apparent paralysis within the outgoing colonial administration, the incoming BDP government secured large supplies of emergency food aid from the newly-established UN World-Food-Programme (WFP), first as drought relief and then for drought recovery. The WFP also provided some stockfeed for the country's cattle, which were 
the primary economic export as well as the major source of wealth and status for the elite. Food aid was distributed through workfare programmes for able-bodied, working-age adults (who were expected to support their dependents), supplementary feeding programmes for school children and other designated vulnerable groups, and additional support for other destitute people (especially the elderly). At least one-third, and perhaps as many as one-half, of the population received food aid at the peak of the drought. The supplementary feeding programmes continued after the end of the drought, and workfare continued intermittently, such that the proportion of the population receiving food aid rarely dropped below one-fifth during the following decade (Seekings 2016a).

When drought recurred in 1978-79, WFP-assisted drought relief again expanded, reaching about 530,000 people - or 80 percent of the population. The government expanded both its public works and destitutes programmes. The Labour-Intensive Public Works Programme would ensure minimal incomes for households with adults capable of work, in non-drought as well as drought years. The new National Policy on Destitute Persons, provided for minimum food and other rations for any individual „who is rendered helpless due to natural disaster or temporary hardship“, and had neither assets (with a limit of four cows) nor close kin to support them (Gooch/Macdonald 1981). These programmes were expanded further in response to the long drought of 1981-87. More than one half of the population was being fed through schools, clinics or other institutions, whilst about 100,000 adults were working on public works programmes (and supporting several hundred thousand dependents) - mostly with food provided through the WFP. A separate programme provided assistance to small farmers. Almost all of the rural population benefitted from one or other drought relief programme (Botswana 1985, 1991; Hay 1988; Munemo 2012). The drought relief and recovery programmes were widely lauded as a success, not only within Botswana but also internationally (see Drèze/Sen, 1989; Teklu 1995; De Waal 1997).

The BDP had not been a mass-based, nationalist movement prior to Independence, and lacked any clear ideology. It was drought that compelled the BDP government to articulate the relationships between and respective responsibilities of citizens and state. Crucially, the state assumed responsibilities supposedly undertaken hitherto by the chiefs. It also adapted existing understandings of chiefly authority and responsibility to accommodate the new state institutions. The result was a doctrine that represented the state as benign, with clear responsibilities to the poor, but which at the same time emphasized the responsibilities of the poor themselves to contribute to their own welfare. Central to this ideology was the concept of kagisano, which was usually translated as „unity, peace, harmony and a sense of community“ (Khama 1972; see Gulbrandsen 2012). This vision of community - associated with rural but not urban society entailed social relationships and norms of responsibility and obligation. Those who could help should assist those who needed help, but the poor had a reciprocal obligation to strive to be self-reliant (and to help others when they could do so). The risk of drought could be socialized, at least in part, but there remained an obligation to self-help or self-reliance (ipelegeng or boipelego in Setswana) (Seekings 2016b).

Self-reliance meant, at the national level, financial independence from the former colonial master, Britain. „As a nation we should not become too accustomed to depend on others; too used to charity from foreigners", warned Khama (1968b; see also Masire 2006: ix). National 
self-reliance required that communities practiced self-reliance also. In his foreword to Botswana's first full National Development Plan, in 1968, Khama urged Batswana „to realise that immediate improvements in living standards can be achieved through individual effort and initiative, rather than through the charity of others" (Khama, 1968a). Batswana should not count on handouts: „If, in a few places, farmers have abandoned their lands - preferring to rely on free food distributed by Government - let me warn them now that there will be no free food for them next year" (Khama 1968b).

Khama's comments about free food reflected disagreements between government departments. At the start of 1968 the Ministry of Agriculture had argued that famine was being perpetuated in part because of "the attitude of the people“:

"A further factor was the attitude that had developed that in times of hardship there was no need to make an effort to overcome the hardship; people had become dependant upon Government to feed them. This was particularly so in the Bakwena where the attitude was, Government has fed us once and will do so again." (BNA 1968-70). ${ }^{4}$

Various senior bureaucrats opined at a meeting that "people had become conditioned to being helped out by Government and were not therefore very anxious to help themselves" (BNA 1968-70a). The Ministry of Agriculture reported later that crops had not been planted in some areas either because of complacency (or „apathy“) or because adults were working on the WFP food-for-work programme:

"It is apparent that last year's food relief programme had severe repercussions on both the people's will to work and the actual mechanics of the harvest - the feeding of destitutes leading to an absence of casual labour which in its turn lead to an even later harvest. The people's return to the villages was delayed until the new season's rains had arrived. The acreage of winter ploughing fell by half and the people expecting either another bumper season or some form of relief did not take advantage of the November rains, the only really effective ones of the season." (BNA 1968-70b).

Through 1968 the Ministry of Agriculture complained repeatedly that famine relief - by „an ever beneficent government" (BNA 1968-70c) - was deterring farmers from planting. This debate was shaped also by the WFP's conditions for providing aid. The WFP's primary role was to provide emergency food aid to tide countries over specific episodes of famine. Once Botswana's drought had broken, food aid was supposed to be developmental, meaning that it contributed to the country becoming more food secure. Any suggestion that food aid might undermine production was a major threat to the WFP operations.

The Ministry of Agriculture's concerns were addressed directly at the end of 1968, when a small team headed by a young Planning Officer in the Ministry of Development Planning investigated food-for-work drought relief projects. Whilst they found serious flaws, which contributed to the completion of few projects, they were generally positive.

"As to whether food-for-work has a disincentive effect on people's attitudes to ploughing, the impression we got was that the disincentive effect is non-existent.

\footnotetext{
${ }^{4}$ The Bakwena are a Tswana group living west of Gaborone.
} 
Wherever we went Ipelegeng workers said they were anxious to go to plough; in several instances, a few had already left. In some cases, women had been replaced by their daughters of about 17 or 18, and the explanation given was that mother had gone to join father to plough and the daughter must earn rations for them whilst they plough."(BNA 1966-70).

The Planning Officer was Festus Mogae, who thirty years later was to become Botswana's third President.

Khama's injunction to farmers to plough stopped a long way short of the denunciation of dependency that became commonplace later (as we shall see below). Anxiety dissipated with good rain and good harvests through most of the 1970s. It did not disappear entirely, however. The government worried about the effects of its support for farmers. In its 1973 National Policy for Rural Development, for instance, the government declared its support for „a subsidy and credit programme“ but „with the qualification that credit and subsidies will be for the purpose of increasing productivity and not in the form of social welfare handouts" (quoted in Devereux 2007: 553). The continued provision of food aid through the school feeding programme was not controversial, but some government departments denounced continuing support for chronic destitutes. The Ministry of Local Government and Lands, which administered the programme, pointed out that most chronic destitutes were either old or disabled. Sceptics, including in the Ministry of Finance and Development Planning, suggested that ablebodied adults were abusing the programme. The Presidency seems to have weighed in on the side of Local Government (see BNA 1974). ${ }^{5}$

There were clear parallels between Khama's emphasis on self-help and self-reliance and the doctrine of self-reliance articulated by Tanzania's president, Julius Nyerere (see Lal, 2012). Khama was aware of Nyerere's writings, but claimed that self-reliance in Botswana was an indigenous concept that had grown out of drought relief: „[W]e in Botswana have not just borrowed a slogan from Tanzania. Our self-reliance has much in common with Tanzania's but it has essentially developed from the need to apply the spirit of Ipelegeng to all aspects of life in Botswana" (Khama 1969). Khama insisted that his was not a socialist ideology (Khama 1970), did not cite Nyerere's 1967 Arusha Declaration, and worked with rather than against private banks and companies. The issue of responsibility, whilst not absent from Nyerere's thought, was more prominent in Khama's speeches. Khama and Nyerere shared some conservative characteristics, but Khama shared few of Nyerere's more radical ones.

Self-help remained very firmly on the agenda in the 1970s, despite improved public finances and good rains. The BDP's 1974 election manifesto declared that the new revenues from the fast-growing mining industry would pay for „basic necessities for most villages. [...] But this does not mean that every village in Botswana will get these facilities immediately or even in the near future, nor will they be supplied entirely free. Above all it does not mean that self-help is any less necessary than it has been in the past." Communities that helped themselves would progress most rapidly (BDP 1974).

When rains failed again in 1978-79, the government was initially slow to act. When Khama finally declared a countrywide drought, he insisted that relief measures were „not going to

\footnotetext{
${ }^{5}$ The government's destitutes policy was finally clarified after the recurrence of drought, in 1980.
} 
be hand-outs to the able-bodied people and those capable of looking after themselves, but drought relief provisions necessary to ensure the survival of the disadvantaged sections of our society" (BNA 1979). Consultants later reported that the government had been worried that that famine relief „would discourage some households from trying to help themselves“ - including especially households that had been rendered destitute by the drought itself - and would therefore "create a welfare dependency" (Vierich/Sheppard 1980: 68; Gooch/Macdonald 1981: 13). Khama's concern over handouts might have been intended in part for the WFP, which had just proposed that it withdraw from Botswana on the grounds that rapid economic growth had raised the country out of the priority list of very poor countries.

The WFP did continue to provide food aid, which the Botswana state continued to provide its citizens with a modest safety net. During drought years, the safety net was expanded to provide additional support for households with working-age, able-bodied adults, who had been pushed into destitution by the drought itself. Food-for-work programmes and supplementary feeding schemes were intended to strengthen families, not compensate for family breakdown. The safety-net was less thorough in non-drought years, but did provide minimal protection against extreme poverty. Provision for permanent destitutes, unable to work and abandoned by kin, was especially minimal. Decommodification was limited by the parsimonious and paternalistic character of the safety net. As a report on the government's droughtrelief operation emphasized, the benefits paid on public works programmes should be „low enough to discourage those who had alternative means of support from coming forward, while enabling those affected by the drought to survive"(Gooch/Macdonald 1981: 126, 129), and should not be higher than the prevailing wage for unskilled labour in normal years. The rations for destitutes could be even smaller, because destitutes needed fewer calories than adults on public employment programmes.

The scale of drought relief operations led to the appointment of consultants to review the experience. In 1981, consultants reported that the 1979/80 drought relief programme had indeed „revealed that free food distribution encouraged a sense of dependency, was damaging to individual self respect and human dignity, and possibly contributed to reduced agricultural production" (Gooch/Macdonald 1981: 120). Their proposed solution was to base drought relief on workfare programmes that paid such a low wage that only the desperate would take the work: A daily wage of 1 Pula „was low enough to discourage those who had alternative means of support from coming forward, while enabling those affected by the drought to survive“ (Gooch/Macdonald 1981: 126). Gooch and Macdonald's proposals entailed a criticism of the 1980 National Destitutes Policy, which made explicit provision for support for ablebodied adults who had been made destitute by „natural disaster or temporary hardship“. In their view, able-bodied adults facing temporary hardship should be compelled to work on public works programmes rather than receive hand-outs.

These views were not reflected in government documents or speeches. The $6^{\text {th }}$ National Development Plan, published in 1985, used the term dependency in a non-judgemental way:

"The scale of dependency is expected to decline markedly when the drought breaks, but many farming households are expected to have difficulties in regaining their former levels of production to the loss of assets, particularly livestock, and to other factors such 
as the migration of the most productive workers away from the farming sector." (Botswana 1985: 20-21).

In this view, impermanent dependency during drought was just. This neutral use of the term dependency was also characteristic of the World Bank at this time. The World Bank's 1980 World Development Report, for example, referred to the „dependent poor - children, the aged and many women" in a similarly non-judgemental way, meaning simply that they were the dependents of others. The Report urged governments to implement measures to improve the lot of these dependent poor (1980: 41). Moreover, none of the local analyses of drought relief, in Botswana in the mid-1980s - including a study commissioned by the government ${ }^{6}$ - echoed the anxiety raised by the external consultants at the time. Local commentators were impressed by the successes of drought relief, not its limits or flaws. Drought relief was viewed as both effective and just. Whatever private concerns the Botswana elite may have had, these prevented neither the 1980 reform of the Destitutes Policy in particular nor the massive drought relief programmes of the 1980s in general.

It was the WFP that first escalated a critical and judgemental discussion of dependency in its reports on drought relief in the mid-1980s. The WFP was increasingly anxious that its envisaged withdrawal from Botswana would be impossible if Botswana permanently needed food aid. In 1987, a WFP-led team examined the possible effects of drought relief on production:

"On the whole, the evidence gathered by the mission in its field visits provides no basis for concern at this time regarding the possible disincentive effects of the various relief measures, including food aid. On the contrary, the mission was informed on several occasions that, in areas suitable for arable agriculture, labour available for relief projects tended to be scarce during the ploughing and harvest seasons, despite the relative attractiveness of the wage offered. Nevertheless, there is a danger that undue prolongation of the relief programme, with its massive coverage and the open-ended nature of some of its activities, would tend to increase the dependency on government assistance of the rural population." (WFP 1987a).

WFP officials worked with Botswana government officials on an application to the WFP for renewed support for feeding programmes. They reported that „both the Government and the WFP have expressed concern about the creation of dependency on free food distribution among the rural population" (WFP 1987b). The number of vulnerable group feeding programme beneficiaries would be reduced, in part through targeting.

When the drought did break, the Government of Botswana appointed a new evaluation of its relief programmes. In the meanwhile, the existing programmes were reined in, although political pressure within Botswana meant that cuts were very much smaller than the WFP had imagined. The consultants reported in 1990, prompting some rethinking in the 7th National Development Plan (published in 1991), a Government Paper in 1992 and a major conference in 1993 (Botswana 1993). Government rethinking was propelled also by a new-found resolve

\footnotetext{
${ }^{6}$ The 1985 study by Hay et al. was commissioned by the Inter-Ministerial Drought Committee. I have not located a copy of the study itself, but its key findings are reported in a subsequent paper by Hay (1988).
} 
on the part of the WFP to effect its long-threatened withdrawal from Botswana. The Government was thus faced with both an assessment of the previous decade's drought relief and the prospect of assuming sole responsibility for financing future programmes.

The new NDP articulated a clear commitment to government action to promote social justice: „The ultimate aim of economic development is to improve the quality of life for all Batswana", it declared (Botswana 1991: 33).

"Every citizen is entitled to a minimum standard of life that is consistent with human dignity. That dignity requires that, as far as possible, people should be enabled to reach such as standard through their own efforts. Wherever possible, Government assistance is aimed at enabling people to become self-sufficient, but there are times and cases where direct income support is necessary - in ensuring that no one goes hungry during a drought, for example, and in providing relief for destitutes." (Botswana 1991: 385).

The priority was raising earnings (through development), but where necessary these would be supplemented through targeted relief to provide the „very poor“ with „a minimum standard of living“. In the longer-term, development would reduce any „dependency on Government“ (Botswana 1991: 33). The NDP endorsed a „social safety net" whilst expressing concern „that the temporary reliance of vulnerable groups on drought relief does not become a permanent dependency“ (Botswana 1991: 389).

The WFP's imminent withdrawal pushed the Government to think more carefully about the design of the programmes that it would now have to fund on its own. This led the Government to distinguish more clearly those categories of deserving citizens for whom dependency was not a problem, i.e. primarily the elderly and children. The Government quickly resolved to assume full financial responsibility from the WFP for feeding programmes for school children (and, when necessary, other vulnerable groups). Provision for the elderly was formalized in 1996 (during another drought) with the introduction of universal old-age pensions, and food baskets for orphans were introduced in 1999 (Ulriksen 2012; Seekings 2016c). These new programmes did not prompt any immediate and public anxiety over dependency among the elite. In the parliamentary debate over the pension reform, only one Member of Parliament for Ngwaketse West, Mr M. R. Thsipinare, even referred to the possibility that government programmes were undermining hard work, and he did so with reference to workfare not the pensions' reform. „If I look beyond this drought I see a bleak picture because our people are no longer willing to engage in activities which can improve their lives", he worried; people ,just want to be engaged in drought relief programmes“ where they enjoyed talking to each other and pretended to work. „It is a job where there is a lot of relaxation and very little being done at the end of the day. This has instilled a habit on our people that is going to take a lot of time to fight off“" (Tshipinare 1996: 8$).^{7}$

At the same time as the old-age pensions were being introduced the government sponsored the drafting of a national vision document. Vision 2016 envisaged a prosperous and just society based on five „national principles“. Four of these - including self-reliance - had been

\footnotetext{
${ }^{7}$ Tshipinare later became Minister for Local Government, responsible for both the old-age pensions and most drought relief operations.
} 
proposed by Khama. The new, fifth principle, botho, referred to the idea that a well-rounded person must realise „his or her potential both as an individual and as a part of the community to which he or she belongs". Together, these five principles should promote "social harmony" (kagisano) through „a compassionate and caring society, offering support and opportunity to those who are poor, and including all people in the benefits of growth" (Botswana 1997: 8, emphasis in original). Growth would hopefully eliminate poverty; in the meantime, "the challenge to Botswana is to provide an adequate and dignified safety net for those who are in poverty in a way that does not encourage dependency and provides a means of escape from the poverty trap and a return to productive society“ (Botswana 1997: 9, 24). At the same time, Botswana should worry about the „deterioration of national values“. In a section on the „,give me attitude“, Vision 2016 insisted on the importance of avoiding „a culture of dependency“ (Botswana 1997: 25).

The following year, Masire handed over the presidency to his deputy, Mogae. Mogae was a trained economist who worked as a technocrat before becoming Minister of Finance and Development Planning, Deputy President and finally President. Mogae had already begun to refine the BDP's ideological position on the social contract between state and citizens. „National development“, he explained in his budget speech in 1993, was „a cooperative endeavour, and we must all play our part.“ Mutual self-responsibility meant „that self-reliance takes precedence over appeals to Government for assistance. Pride in self-reliance must be nurtured; it cannot be allowed to be displaced by a dependency syndrome“ (Mogae 1993: 4). This message was reiterated in the 1994 and 1999 election manifestoes (BDP 1994; Mogae 1999).

Mogae's discourse of mutual self-responsibility was a much stronger version of the discourse of self-help and responsibility developed under Seretse Khama. During the long drought of the 1980s, the emphasis had understandably shifted to the responsibilities of the state. The combination of recurrent drought in the first half of the 1990s and the withdrawal of the WFP shifted attention back to what citizens should be doing to improve their long-term food security. Concern over dependency has not prevented the further expansion and institutionalization of a welfare state, providing especially for children and the elderly, but it had become commonplace to refer to the challenge of reducing dependency, i.e. among workingage, able-bodied adults.

\section{Dependency and the respecification of the welfare state in the $2000 \mathrm{~s}$}

Mogae became president during continued rethinking about who precisely was deemed deserving of public assistance. The first years of his presidency saw the introduction of benefits for orphans, in response primarily to AIDS, and the reform of national policy on destitutes. Within both state and society, however, concern was rising over the dependency of the poor on the state. Mogae himself seems to have been preoccupied primarily with the affordability of public programmes. In 2008, Mogae handed over the presidency to former army general Ian Khama, the oldest son of founding president Seretse Khama. Under Khama, the state rejected proposals for the expansion of social assistance programmes and instead expanded massively workfare, prompting a fresh round of anxiety about dependency. 
Provision for destitutes, unlike provision for the elderly or orphans, raised the issue of dependency, insofar as adults who might otherwise work could be considered destitute. The 2002 Revised National Policy on Destitute Persons, completed during yet another drought, redefined destitution to refer, primarily, to someone who, due to age or infirmity, was unable to support themselves, had insufficient assets and lacked kin. Special provision was made for „needy children“. In addition, however, people could be temporarily destitute as a result of drought or the death or illness of (or desertion by) their breadwinner. An Operating Manual listed "indicators of destitution" to ensure that provision was targeted correctly, i.e. strictly. These included „house in poor shape and poorly cleaned“, „no firewood and no food being cooked“, "tattered blankets and clothing“ and the presence of children scavenging in dustbins or rubbish dumps (Botswana, 2002).

For the first time, the state acknowledged that destitution might affect entire households, not isolated individuals, reflecting social and economic changes in society (see Nasha 2002). At the same time, destitution continued to be seen as entailing an element of delinquency, i.e. a failure to take advantage of opportunities to improve one's life. The 2002 Revised Policy may have been more generous than the 1980 version, but it remained highly moralistic. The Policy warned explicitly that "there exists a fine line between providing destitute persons with a reasonable level of benefits that will motivate them to use their best efforts to escape the poverty trap on the one hand and reaching a level where those very same benefits serve as a disincentive to such persons making an effort to obtain a sustainable livelihood on the other hand". It also listed the responsibilities of beneficiaries, which included „to make the most out of the rehabilitation opportunities that are provided by the Government" and "to make reasonable efforts to find sustainable employment if they are physically and mentally able“. The Policy specified appropriate actions to be taken if destitutes "flouted“ their responsibilities (Botswana 2002: 10-12). In parliament, speaker after speaker pointed to abuses (such as spending money on beer) as well as the mental incapacity of destitutes (Parliament of Botswana 2002).

Anxiety over dependency seems to have risen in the 2000s. A review of anti-poverty initiatives in 2002 reportedly found that „many of the relatively well-off respondents, including civil servants, expressed concern“ over the possibility that policies might result in a "culture of dependency" that exacerbated poverty (cited in UNDP 2005: 18). The United Nations Development Programme concluded that government policies had the "unintended but inevitable outcome of [...] an unhealthy dependence on the state“, such that state provision had "become a trap" (UNDP 2005: 18). Soon after, social media began to report similar views. An official inquiry into provision for children reportedly quoted one social worker complaining that kin were no longer helping each other because the government had stepped in. A second social worker was quoted as saying that „the government is spending too much on handouts rather than actually building up the person, which I think makes the situation worse because I don't see them really standing up or being independent, because government sort of does anything for them“. Instead, this social worker suggested, „people need to be taught how to be self-sufficient and not to rely on government“: „Fewer handouts, and more education“ (Hu 2011).

When the National Destitute Policy was again reviewed, in 2008, it was recommended that able-bodied destitutes should be enrolled in workfare (see Matambo 2010). This required that 
the workfare programme be extended to all parts of the country where there were able-bodied destitutes. The former Labour-Intensive Public Works programme was transformed into the Ipelegeng programme. The number of registered destitutes declined at the same time as a massive expansion of workfare (Botswana 2017). Despite this, the Minister of Finance warned that the number of people receiving assistance was „economically unsustainable“ (Matambo 2010), pointing to the 180,000 registered old-age pensioners, orphans and destitutes. Mokgweetsi Masisi, Minister for Presidential Affairs and Public Administration, briefing the media on another review of the government's anti-poverty policies in 2010, insisted that the government would avoid handouts that created dependency. When a team of consultants (from the UK and Botswana) proposed a new child grant along the lines of the Child Support Grant in neighbouring South Africa, politicians reportedly shot down the proposal on the grounds that it would encourage dependency and laziness. ${ }^{8}$ Three years later, the government rejected another proposal for a Family Support Grant, made by a team from the World Bank and the locally-based agency BIDPA (BIDPA/World Bank 2013). Even workfare began to attract criticism, as Ipelegeng participants failed to exit or graduate into independent livelihoods and the total number of participants rose (BIDPA 2012).

The actual beneficiaries of workfare programmes did not share the view that workfare encouraged laziness. They attributed their inability to graduate into independent livelihoods to the absence of real opportunities for either self-employment or employment. Indeed, some of the people interviewed for one study were reportedly „surprised that they were expected to graduate given their debilitating poverty“. One participant was quoted as saying that „I cannot live without Ipelegeng, I will die of hunger“ (BIDPA 2012: 161). Nor was anxiety over dependency universal among elites. In Parliament, MPs such as M. K. Mzwinila (then BNF, MP for Gaborone North; subsequently BDP MP for Mmadinare) occasionally dissented from the hegemonic position, asserting (for example) that „destitutes are ordinary people just like ourselves" and were indeed "the same people who have the intelligence to go to the polls and vote for us" (Mzwinila 2002: 173-174). Trade unions and NGOs proposed the expansion of welfare programmes (e.g. BFTU 2007). Such views were, however, dissenting ones.

In the 2010s, elite and middle-class anxiety over dependency became as pronounced with respect to workfare as it had earlier with respect to drought relief and provision for destitutes. The 11th NDP, published in 2017, acknowledges the state's responsibilities to all its citizens but emphasizes the provision of opportunities for the poor to help themselves. In the chapter on Social Upliftment, a section on challenges opens with a statement about dependency: „Although appreciable strides have been made to uplift the wellbeing of citizens, increasing dependence on support programmes has been observed, and the current relief programmes tend to compete with those that have an empowerment component". Later, the NDP points to the „need to reduce dependence on support programmes by up scaling the provision of life skills to empower beneficiaries. A deliberate strategy for graduating people out of such dependence will need to be developed with a view to making the schemes sustainable“ (Botswana 2017).

\footnotetext{
${ }^{8}$ I am grateful to Isaac Chinyoka for this information.
} 


\section{The discourse of dependency in comparative perspective}

When drought beset newly-independent Botswana, Seretse Khama and his government did not hesitate to mobilise national and especially international support for drought relief. Food (and even some stockfeed) was secured through, primarily, the WFP. After the drought broke, food aid continued for ostensibly developmental feeding schemes and, intermittently, foodfor-work programmes. Khama, Masire and the BDP articulated an ideology that presented such government welfare programmes as the responsibility of the state to the citizens. Citizens themselves had a reciprocal responsibility to strive for self-reliance. In the late 1960s and early 1970s, some government officials - including in the Ministries of Agriculture and of Finance and Development Planning - worried that food-for-work programmes and provision for destitutes were discouraging farmers from planting or others from working, but these concerns remained subordinate to the commitment to public responsibility.

Between the late 1970s and 1990s, however, concern over the dependency of the poor on handouts intensified and spread. It was propelled in part by the expansion of public provision in response to successive droughts (especially in 1978-79, 1981-87 and 1992-93), i.e. by the scale (in terms of coverage) of Botswana's welfare state. This concern was articulated first by external consultants and the WFP, and only later entered official government discourse, although it is possible that government officials within Botswana were privately concerned earlier than their public discourse suggests. Foreign consultants and the WFP were concerned because continuing dependency on drought relief ran counter to their missions. Consultants were concerned with development, which was understood as enhancing the capacity of poor people to raise themselves out of poverty. The WFP was concerned because its mission was, primarily, to provide temporary emergency relief, and secondarily to promote development in order to improve food production (or food security) and obviate the need for future emergency relief. Discourses of development were taken up, and privileged, within Botswana's state also. The expansion of anxiety over dependency was thus driven by the expansion of welfare programmes, on the one hand, and the privileging of economic development in the policy discourse, on the other. It did not require strong or direct evidence that citizens were dependent on handouts in the sense that this had any negative effects on work.

The withdrawal of the WFP accelerated the institutionalization of the welfare state in the 1990s, with the introduction of programmes directed specifically at the elderly, orphans and other destitutes, and the expansion of workfare. These programmes were seen as fulfilling the state's responsibility to its citizens. Yet poverty persisted. This was taken as evidence enough that the poor were resisting the opportunities apparently provided by a state that saw itself as developmental. In this view, the poor were not fulfilling their obligations, their reciprocal responsibility. By the 2000s, dependency was widely and routinely denounced by members of Botswana's elite and middle classes.

This discourse of dependency was thus bound up with understandings of both reciprocity and development. The discourse of dependency built on the pre-existing normative emphasis on the social obligations of responsibility and reciprocity. Dependency marked the breakdown of reciprocity, through the failure of poor people to fulfil their moral responsibilities to the broader community, to strive to prosper and become productive members of the community, 
willing and able to help others in turn. In the 1990s, Mogae emphasized mutual responsibility as the antidote to dependency. Dependency also reflected the failure of development. Supposedly successful developmental programmes should not only ensure survival through periods of drought but also help the poor to raise themselves out of poverty, ideally through the acquisition of human capital or other assets. Development meant that any dependency on handouts should be temporary, until beneficiaries graduated off programmes as they prospered and became better able to stand on their own feet. Chronic dependency thus marked the failure of development. Poverty increasingly came to be viewed not in terms of social and economic relationships but rather as a matter of individual incentives. If poverty persisted, it must be because government handouts reduced the incentive to work, to become self-reliant, and to prosper.

By the 2010s, dependency seems to have become associated with workfare, which provided minimum income to young men and women in Botswana's fast-growing towns. The discourse had its roots in the countryside, however, and specifically in the relationships between small farmers, struggling with drought and the transformation of agriculture, more prosperous farmers, and the state. With its roots in an agrarian conception of reciprocal responsibility and personhood, and specific policy responses to drought, the discourse of dependency originated as an agrarian doctrine of welfare. The doctrine was articulated by the conservative elite leading the BDP - an elite which, despite economic growth and change, remained heavily invested in cattle that constituted an important pillar of the status order.

This is not to say that attitudes towards welfare were unchanging. A series of anthropologists have pointed to important cultural shifts in the form of changing norms around the obligations of kinship. Dahl shows that there was widespread criticism of the ways in which kin neglected the rising number of AIDS orphans. Households sometimes appropriated orphans opportunistically, in order to access for the household the food baskets provided by the state for the orphan. Moreover, Dahl shows, this criticism of the failings of individual kin extended to criticism of kinship and supposedly traditional culture in general. Growing numbers of Batswana turned to Christian churches - including Pentecostal churches - that preached a morality critical of kin-based caregiving and offering in its place „new forms of community, sociality, and material support, both imagined and actual“ (Dahl 2009: 26). Changing norms both preceded policy reform, in that the inability or unwillingness of people to care for kin pushed the state to expand public provision, and its consequence, in that state programmes reshaped distribution, power and values within families (see also Dahl 2014, 2016; Livingstone 2005; Durham 2007). It is likely that it was the combination of newly heightened anxiety over the decline of traditional kinship (and community) and the emerging suspicion that welfare programmes were implicated in this that fueled elite denunciations of dependency.

Concern over dependency may have inhibited the expansion of the welfare state in Botswana, but it clearly did not prevent it. During the fifty or so years following Independence, feeding programmes, workfare and dedicated support for destitutes steadily expanded. In the 2010s, feeding programmes, together with benefits for pensioners, orphans and approved destitutes, continue to cover a large proportion of the population. Workfare - which was originally seen as the solution to dependency - has expanded massively. This expansion reflects in part the strong political incentives facing the BDP, regardless of BDP leaders' anxiety over 
dependency. As early as 1985, Holm and Morgan observed presciently that it would be politically very difficult to unravel drought relief programmes. The BDP had come to view drought relief as „a very effective means of reinforcing its rural support“: „What the civil servants once had urged on the politicians with great difficulty, the latter have now come to perceive as an important means to obtain re-election" (1985: 476). Four years later, Molutsi reported that a survey showed that drought relief was the single most important reason given by respondents for membership of the BDP (1989: 128). Indeed, Gulbrandsen (2012) argues, drought relief was integral to the overall relationship between citizen and the state (i.e. motswadintle, "he from whom good things come" - Helle-Valle, 2002: 195-6). Strong pressure on the ruling BDP from the opposition parties rendered the BDP averse to rolling back popular programmes. A dramatic decline in the BDP's votes in 1994, and the threat of defeat in the 2000s, pushed the party to expand rather than retrench the reach of public programmes (Hamer 2016; Seekings 2016c).

The BDP's support for welfare programmes in practice surely reflects more than just the incentives arising from political competition. Whilst the discourse of dependency has become more and more prominent over time, it remains just one element in the overall ideology of welfare. The discourses of responsibility and social justice have not disappeared. In the face of enduring poverty and inequality, as well as intense political competition, the BDP government continues with workfare and feeding programmes, as well as social pensions for the elderly and support for some other categories of deserving poor. But the strong normative objections to welfare programmes within the elite mean that benefits remain parsimonious. When oldage pensions were introduced, for example, they were set at one quarter of the value of the pension in neighbouring South Africa. As Ulriksen (2017) emphasizes, successive governments of Botswana have also been reluctant to raise taxation to the level of some other middle-income countries, limiting the funds available for social programmes.

A discourse of dependency and criticism of handouts is not unique to Botswana. Interviews with government ministers and officials in more than ten African countries suggest that it is widespread, at least in Anglophone East and Southern Africa. ${ }^{9}$ Kalebe-Nyamongo's interviews with the members of the elite in Malawi demonstrate that negative attitudes to the poor are widespread in that country (Kalebe-Nyamongo/Marquette 2015). Rival presidential candidates in the 2014 election used the issue of dependency to bash the briefly incumbent president, Joyce Banda (Hamer/Seekings 2017). In Ethiopia and Rwanda, the authoritarian regimes led by Meles and Kagame denounced dependency and insisted on the imperative of work. For Kagame, the peasantry was undynamic and needed to be modernised. Poverty was seen as the consequence of a lack of determination. „If we can utilize the resources that God has given to us to good effect, we can eradicate poverty“, Kagame told the country in 2000. „We would like to urgently appeal to the Rwandese people to work. As the Bible says, ,he who does not work should not eat" (cited in Ansoms 2009: 297; see also Lavers 2016a, also on Rwanda and 2016b on Ethiopia). In South Africa, where grants or pensions are paid every month for one in every three citizens, a conservative criticism of dependency on handouts has long existed within the

\footnotetext{
${ }^{9}$ Country case-studies of reforms in Ghana, Uganda, Kenya, Tanzania, Malawi, Zambia, Zimbabwe and Lesotho (as well as Botswana) have been published as Working Papers from the Legislating and Implementing Welfare Policy Reforms (LIWPR) research programme at the University of Cape Town (www.cssr.uct.ac.za/liwpr).
} 
ruling party, and seems to have grown in the 2000s (Meth 2004; Seekings 2015; Button et al. 2017). The discourse persists despite many empirical studies that suggest that social grants and pensions have positive short and perhaps even long-term effects on poverty (see Davis et al. 2016).

In some of these countries, such as Zambia and Tanzania, an aversion to dependency on handouts from the state seems to have impeded the introduction of cash transfer programmes. In others, including notably South Africa, it appears to be in part a response to the scope of existing programmes. Across most of the region, however, interviewee after interviewee says that people „should not get something for nothing“. The prevalence of this mantra suggests that ideas about reciprocity are deeply entrenched among African elites. Conversely, few elite interviewees refer to government programmes in terms of individual or other rights. Social citizenship may be expanding in practice across much of Africa, but claims are usually restricted to a very bare minimum and rarely on a normative basis of rights.

A reactionary discourse of dependency is not uniquely African. Daniel Moynihan famously declared in 1973 that, in the USA "the issue of welfare is the issue of dependency“: „To be poor is an objective condition; to be dependent, a subjective one as well [...] Being poor is often associated with considerable personal qualities; being dependent rarely so" (quoted in Fraser/Gordon 1994: 309). Fraser and Gordon (1994) document the shifting discourse of dependency from pre-industrial England to the USA in the late twentieth century. In preindustrial England, dependency meant little more than subordination, without negative moral connotations; independence (and citizenship) were based on property-ownership. With industrialization, however, its meaning shifted to refer to people who remained outside of the system of wage labour. Dependency became shameful, deviant, and stigmatized. The pauper ceased to mean someone who was poor, and instead came to mean someone who was dependent on poor relief rather than wages. Paupers were seen as degraded, their characters corrupted, perhaps inherited from their parents, perhaps due to chronic reliance on charity. "To be a pauper was not to be subordinate within a system of productive labour; it was to be outside such a system altogether" (Fraser/Gordon 1994: 317). In the USA, dependency later became racialized and gendered, and even more deeply stigmatized. Initially, black slaves were singled out as dependent because they were outside of the system of wage labour. With the rise of the family model based around male breadwinners, women also came to be seen as dependent. In the twentieth century dependency came to be associated with welfare, which meant stigmatised non-contributory programmes without links to employment, whilst contributory programmes (i.e. social insurance, against the risks of unemployment and old-age) linked to employment were viewed as entitlements. The meaning of dependency may have shifted again as large parts of the USA became postindustrial, as it became associated more explicitly associated with pathologies such as drug abuse.

In another paper, Fraser and Gordon (1992) emphasise the roots of the American discourse of dependency in the contrast between contract and charity. In the USA, individuals are recognized as having rights to social insurance programmes because of the contractual link between contributions and benefits. Social insurance schemes therefore do not provide something of nothing. Charity, in contrast, comprised gifts, on to which the recipient had no 
right and the donor no obligation. Non-contributory welfare programmes came to be seen as charity. Chronic dependency on charity was, of course, deeply stigmatizing.

The discourse of dependency in Botswana, and Africa more generally, differs from this American version in many respects, although it has come to share the negative connotations. As Fraser and Gordon (1992) emphasise, the American contrast between contract and charity precluded the possibility of the kind of noncontractual reciprocity that might constitute social citizenship in the sense of rights-bearing membership of a community. Independence meant entering into contractual relations on the basis of waged employment. Dependency meant having no contractual (and hence legitimate) claims on account of a lack of previous or current employment.

In Africa, the concept of dependency has a different genealogy, and a slightly different meaning. Its origins are more agrarian than industrial, and the social dimension is important. Dependency has an economic element, in that dependent people are deemed to be working insufficiently to raise themselves out of poverty and economic dependency. At the same time, however, it has a fundamentally social character. Dependency marks the breakdown of reciprocity and the triumph of the individual over the social. Dependency is denounced not because it results from the lack of individual autonomy, as in the USA, but for precisely the opposite reason, i.e. because it entails individual autonomy from reciprocal social relationships.

Ferguson proceeds to distinguish between illegitimate and legitimate dependency. Dependency is legitimate when it occurs within relationships of social inequality, i.e. when dependents are dependent on better-off kin or neighbours with whom they have ongoing, prospectively reciprocal relationships entailing responsibilities on both sides. In the absence of such social relationships, inequality is asocial, and the ensuing dependency on the state is asocial and hence illegitimate. The rise of the discourse of dependency in Botswana - and elsewhere in Africa - reflected anxiety over a shift from social to asocial inequality. Its roots lay in social relationships and modes of production in the past, when land was imagined to have been abundant and production to have been limited by labour. In the 1980s, 1990s and 2000s, dependency came to be seen as the inability or failure to work, but the work was not so much wage labour as peasant production, and the norms being violated were the obligations associated with peasants and kin in an agrarian society where personhood itself was understood to be social. The economic reality, of course, was changing rapidly. With few prospects for either a renewal of peasant agriculture or a sharp increase in employment for less skilled labour, poor households and individuals have little choice but to declare their dependency on kin, neighbours or the (welfare) state. „For while ,dependency' is obsessively decried as a problem or a trap in social policy discourse, an ethnographic view suggests that it is really only via relations of ,dependence“ that most of the population survives at all“, Ferguson argues; „Dependence is, in this respect, not the name of the problem; it is the name of the solution" (2015:97). How this might be squared with elites' expectations that the dependent poor fulfil their reciprocal responsibilities is not clear. 


\section{References}

Ansoms, An (2009). Re-engineering Rural Society: The Visions and Ambitions of the Rwandan Elite. African Affairs 108 (431), 289-309.

BDP (1974). BDP Election Manifesto 1974. Gaborone: Botswana Democratic Party.

BDP (1994). BDP Election Manifesto 1994. Gaborone: Botswana Democratic Party.

BFTU (2007). Policy Position Paper on Social Security and Social Protection in Botswana - 2007. Gaborone: Botswana Federation of Trade Unions.

BIDPA (2012). Final Report for the Review of the Ipelegeng Programme. Gaborone: Botswana Institute for Development Policy Analysis.

BIDPA, World Bank (2013). Botswana Social Protection Assessment. Gaborone: Botswana Institute for Development Policy Analysis and Washington DC: World Bank.

Botswana National Archives (BNA) (1966-70). File OP 18/2. Festus Mogae et al., Report of Appraisal Team on Progress of Ipelegeng Food for Work Projects, dated 19.12.1968.

Botswana National Archives (BNA) (1968-70). File OP 18/3. Gaborone.

Botswana National Archives (BNA) (1968-70a): File OP 18/3 1968-70. P/S Ministry of Works and Communications, to P/S MLG\&L, 19.4.1968.

Botswana National Archives (BNA) (1968-70b). File OP 18/3. Report signed by R.E.H. Atkinson, dated 15.5.1968.

Botswana National Archives (BNA) (1968-70c). File OP 18/3. Letters, P/S Min of Ag to P/S Presidency (Archie Mogwe) et al., dated 29.7 and 13.9.1968.

Botswana National Archives (BNA) (1974). File MLGL 25/2. Cabinet Memorandum on „Social Welfare: ,Chronic'Destitutes" and Accompanying Correspondence. February and September 1974.

Botswana National Archives (BNA) (1979). File OP/21/2. Official Drought Declaration of 25.5.1979.

Botswana (1985). National Development Plan 6. Gaborone: Ministry of Finance and Development Planning.

Botswana (1991). National Development Plan 7, 1991-1997. Gaborone: Ministry of Finance and Development Planning.

Botswana (1993). Report on the National Conference on Drought Management. Gaborone: Ministry of Finance and Development Planning.

Botswana (1997). Vision 2016. Gaborone: Government Printer.

Botswana (2002). Revised National Policy on Destitute Persons. Gaborone: Ministry of Local Government and Rural Development.

Botswana (2017). Draft National Development Plan 11. Gaborone: Ministry of Finance and Development Planning.

Button, Kirsty, Elena Moore and Jeremy Seekings (2017). South Africa's Hybrid Care Regime: The Changing and Contested Roles of Individuals, Families and the State After Apartheid. CSSR Working Paper 404. Centre for Social Science Research, University of Cape Town. 
Dahl, Bianca (2009). The „Failures of Culture“: Christianity, Kinship, and Moral Discourses about Orphans During Botswana's AIDS Crisis. Africa Today 56 (1), 23-43.

Dahl, Bianca (2014). „Too Fat to Be an Orphan“: The Moral Semiotics of Food Aid in Botswana. Cultural Anthropology 29 (4): 626-47.

Dahl, Bianca (2016). The Drama of De-orphaning: Botswana's Old Orphans and the Rewriting of Kinship Relations. Social Dynamics 42 (2), 289-303.

Davis, Benjamin, Sudhanshu Handa, Nicola Hypher, Natalia Winder Rossi, Paul Winters and Jennifer Yablonski (eds.) (2016). From Evidence to Action: The Story of Cash Transfers and Impact Evaluation in Sub-Saharan Africa. Oxford: Oxford University Press, with the FAO and UNICEF.

Devereux, Stephen (2007). Social Pensions in Southern Africa in the Twentieth Century. Journal of Southern African Studies 33 (3), 539-60.

De Waal, Alex (1997). Famine Crimes: Politics and the Disaster Relief Industry in Africa. Oxford: James Currey/IAI.

Drèze, Jean, and Amartya Sen (1989). Hunger and Public Action. Oxford: Clarendon Press.

Durham, Deborah (2007). Empowering Youth: Making Youth Citizens in Botswana. In: Cole, Jennifer and Deborah Durham (eds.). Generations and Globalization: Youth, Age, and Family in the New World Economy. Indiana: University Press.

Ferguson, James (2015). Give a Man a Fish: Reflections on the New Politics of Distribution. Raleigh, NC: Duke University Press.

Fraser, Nancy, and Linda Gordon (1992). Contract versus Charity: Why Is There No Social Citizenship in the United States? Socialist Review 22 (3): 45-67.

Fraser, Nancy and Linda Gordon (1994). A Genealogy of Dependency: Tracing a Keyword of the U.S. Welfare State. Signs 19 (2) 309-36.

Garcia, Marito, and Charity M. T. Moore (2012). The Cash Dividend: The Rise of Cash Transfer Programs in Sub-Saharan Africa. Washington D.C.: World Bank.

Gooch, Toby, and John Macdonald (1981). Evaluation of 1979/80 Drought Relief Programme. Gaborone: Ministry of Finance and Development Planning.

Gulbrandsen, Ørnulf (1996). Poverty in the Midst of Plenty: Socio-economic Marginalization, Ecological Deterioration and Political Stability in a Tswana Society. Bergen: Norse Publications.

Gulbrandsen, Ørnulf (2012). The State and the Social: State Formation in Botswana and its Precolonial and Colonial Genealogies. New York: Berghahn.

Hamer, Sam (2016). „Our Father's Programmes“: Political Branding Around Social Protection in Botswana, 2008-2014. CSSR Working Paper 370. Centre for Social Science Research, University of Cape Town.

Hamer, Sam and Jeremy Seekings (2017). Social Protection, Electoral Competition, and Political Branding in Malawi. UNU-WIDER Working Paper 2017/99. Helsinki: UNU-WIDER.

Hay, Roger W. (1988). Famine Incomes and Employment: Has Botswana Anything to Teach Africa? World Development 16 (9), 1113-25. 
Helle-Valle, Jo (2002). Seen From Below: Conceptions of Politics and the State in a Botswana Village. Africa 72 (2), 179-202.

Hu, A. (2011). Government Aid, Possible Dependency. Blog: Voices of the Youth. The Experiences of a Fulbright Fellow in Botswana. https://amandainbotswana.wordpress.com/2011/03/12/government-aid-possible-dependency/. Last access 12.12.2017.

Holm, John, and Richard G. Morgan (1985). Coping With Drought in Botswana: an African Success. Journal of Modern African Studies 23 (3), 463-82.

Kalebe-Nyamongo, Chipiliro, and Heather Marquette (2014). Elite Attitudes Towards Cash Transfers and the Poor in Malawi. DLP Research Paper 30. Developmental Leadership Programme, University of Birmingham.

Khama, Seretse (1968a). Foreword to the National Development Plan, 1968-73. Gaborone: Government Printer.

Khama, Seretse (1968b). Presidential Address to the National Assembly, at the First Meeting of the Third Session of the First National Assembly on the 9.12.1968.

Khama, Seretse (1969). Address to the Teachers' Union Conference, Lobatse, 15.12.1969.

Khama, Seretse (1970). Botswana - A Developing Democracy in Southern Africa. Speech Given in Uppsala, Sweden, 11.11.1970, published by Scandinavian Institute of African Studies.

Khama, Seretse (1972). Address on Kagisano - A Policy for Harmony, at the 11th Annual Conference of the BDP, Francistown, 1.4.1972.

Lal, Priya (2012). Self-reliance and the State: the Multiple Meanings of Development in Early Postcolonial Tanzania. Africa 82 (2), 212-34.

Lavers, Tom (2016a). Understanding Elite Commitment to Social Protection: Rwanda's Vision 2020 Umurenge Programme. UNU-WIDER Working Paper 2016/093. Helsinki: UNU-WIDER.

Lavers, Tom (2016b). Social Protection in an Aspiring Developmental State: The Political Drivers of Ethiopia's PSNP. UNU-WIDER Working Paper 2016/130. Helsinki: UNU-WIDER.

Livingston, Julie (2005). Debility and the Moral Imagination in Botswana. Bloomington: Indiana University Press.

Magang, Davi (2008). The Magic of Perseverance: The Autobiography of David Magang. Cape Town: Centre for Advanced Studies of African Society.

Makgala, Christian John (2013). Discourses of Poor Work Ethic in Botswana: A Historical Perspective, 1930-2010. Journal of Southern African Studies 39 (1), 45-57.

Masire, Quett Ketumile Joni (2006). Very Brave or Very Foolish? Memoirs of an African Democrat. Gaborone: Macmillan Botswana.

Matambo, Kenneth. (2010). Budget speech. Hansard, 163 (1), 8.2.2010.

Meth, Charles (2004). Ideology and Social Policy: Handouts and the Spectre of Dependency. Transformation 56 (1), 1-30.

Mogae, Festus (1993). Hansard, 110 (1), 8.2.1993.

Mogae, Festus (1999). Foreword to BDP Election Manifesto 1999. Gaborone: BDP. 
Molutsi, Patrick (1989). Whose Interests Do Botswana's Politicians Represent. In: John Holm and Patrick Molutsi (eds.). Democracy in Botswana. Gaborone: Macmillan, 120-32.

Munemo, Ngonidzashe (2012). Domestic Politics and Drought Relief in Africa. Boulder: Lynne Rienner.

Mzwinila, Michael Kefentse (2001). Hansard, 24.7.2002.

Nasha, Margaret (2002). Hansard, 139 (5), 22.7.2002.

Parliament of Botswana (2002). Hansard, 139 (5), 22-24.7.2002.

Seekings, Jeremy (2015). Income Support through the Welfare State. In: Seekings, Jeremy and Nicoli Nattrass. Policy, Politics and Poverty in South Africa. London: Palgrave, 133-61.

Seekings, Jeremy (2016a). Drought Relief and the Origins of a Conservative Welfare State in Botswana, 1965-1980. CSSR Working Paper 378. Centre for Social Science Research, University of Cape Town.

Seekings, Jeremy (2016b). „A Lean Cow Cannot Climb out of the Mud, but a Good Cattleman Does Not Leave it to Perish": The Origins of a Conservative Welfare Doctrine in Botswana under Seretse Khama, 1966-1980. CSSR Working Paper. Centre for Social Science Research, University of Cape Town.

Seekings, Jeremy (2016c). Building a Conservative Welfare State in Botswana. CSSR Working Paper 388. Centre for Social Science Research, University of Cape Town.

Seekings, Jeremy (2016d). Welfare Regimes and Distribution across the Global South: Theory and Evidence in the Construction of Typologies. CSSR Working Paper 394. Centre for Social Science Research, University of Cape Town.

Seekings, Jeremy (2018, forthcoming). Are African Welfare States Different? Welfare State-building in (Anglophone) Africa in Comparative Perspective. CSSR Working Paper. Centre for Social Science Research, University of Cape Town.

Teklu, Tesfaye (1995). Labour-intensive Public Works in Botswana and Tanzania. In: von Braun, Joachim (ed.), Employment for Poverty Reduction and Food Security. Washington DC: International Food Policy Research Institute, 144-73.

Tshipinare, Michael (1996). Hansard, 19.2.1996.

Ulriksen, Marianne (2012). Welfare Policy Expansion in Botswana and Mauritius: Explaining the Causes of Different Welfare Regime Paths. Comparative Political Studies 45 (12) 1483-1509.

Ulriksen, Marianne (2017). Mineral Wealth and Limited Redistribution: Social Transfers and Taxation in Botswana. Journal of Contemporary African Studies 35 (1) 73-92.

UNDP (2005). Botswana Human Development Report 2005: Harnessing Science and Technology for Human Development. Gaborone: United Nations Development Programme.

Vierich, Helga, and Christopher Sheppard (1980). Drought in Rural Botswana: Socio-economic impact and government policy. Gaborone: Ministry of Agriculture, January.

WFP Archives (1987a). Interim Evaluation Summary Report: Botswana 324 EXP 3, Agenda Item 16, $23^{\text {rd }}$ Session of WFP Committee on Food Aid, Rome, 25.5. - 5.6.1987.

WFP Archives (1987b). Project Botswana 324 (EXP.4), submitted to WFP Committee on Food Aid for approval, at $23^{\text {rd }}$ Session of the CFA, Rome, 25.5. - 5.6.1987. 
World Bank (1980). World Development Report 1980. Washington DC: World Bank. 